УДК 339.137 .2

DOI: https://doi.org/10.37320/2415-3583/7.10

Марченко В.М.

доктор економічних наук, професор кафедри економіки та підприємництва, Національний технічний університет «Київський політехнічний інститут імені Ігоря Сікорського»

\title{
ПРАКТИЧНИЙ ДОСВІД РЕАЛІЗАЦІЇ КОНКУРЕНТНИХ СТРАТЕГІЙ ПІДПРИЕМСТВ
}

\begin{abstract}
Метою статті є порівняльний аналіз чинників формування та найкращьӧ практики реалізації конкурентних стратегій підприємствами України. Опис практики реалізації конкурентних стратегій підприємствами лідерами відповідних ринків дав змогу ідентифікувати еволюиію основних засобів становлення їх конкурентоспроможності та узагальнити основні чинники, які впливають на формування конкурентних переваг підприємства на ринку та визначають ефективність реалізації вибраної конкурентної стратегії. Виявлено, що такими чинниками є здатність підприємства впливати на поведінку споживача через спрямований інформачійний потік та унікальні властивості товару, здатність задовольнити споживчий попит за найменших витрат, шо досягається шляхом формування замкнутих технологічних ичиклів та логістичних ланиюгів, здатність підтримувати лідерство на ринку завдяки реалізаиї політики постійного товарного оновлення. Інструментами реалізації визначених здатностей є інновації та нестандартні стратегічні рішення. Виявлено, що в сучасній економіці спостерігаються суттєві зміни як у споживчих потребах (індивідуалізація потреб), так і в інструментах їх задоволення (персоніфікація продажів). Конкурентними перевагами підприємства, які забезпечують їх конкурентоспроможність та відповідність споживчим потребам, є структура портфеля асортиментних позицій та товарних марок, інформаційний супровід властивостей продукиіi, підтвердження їх безпечності та якості, формування повних технологічних ичиклів виробництва та логістичної інфраструктури, інноваційне оновлення виробництва, наявність науково-дослідних иентрів та виробництво пробних зразків продукиіі. Зміни вподобань і стилю споживчої поведінки в сучасному світі трансформують як ринок, так і поведінку його учасників. Встановлено, щя в сучасних умовах ринкової економіки поведінка споживача на ринку є основним джерелом ефективності конкурентної стратегї. Відмінність набула ознак властивості сучасного товару, а першість у пропозиції інноваційного товару на ринку забезпечує прибутковість підприємства.
\end{abstract}

Ключові слова: конкурентні стратегї, конкурентні переваги, конкуренція підприємства, поведінка споживачів.

Постановка проблеми. Згідно 3 дослідженнями Всесвітнього економічного форуму (ВЕФ) за рівнем індексу глобальної конкурентоспроможності (Global Competitiveness Index, GCI) українські підприємства демонструють тенденцію погіршення своїх конкурентних переваг. Так, у 2012 році Україна у GCI посідала 73 місце зі 144 країн, у 2013 році - 84 зі 148 країн, у 2014 році - 76 місце зі 144 країн, у 2015 році - 79 місце зі 140 країн, у 2016 році - 85 місце зі 138 країн, у 2017 році 81 місце зі 137 країн, а у 2018 році - 83 місце зі 140 країн. Проведене дослідження свідчить про невпинне падіння здатності українських підприємств конкурувати як на традиційних, так і на нових ринках та необхідність імплементації найкращого досвіду стратегій конкуренції в практику діяльності українських підприємств [5].

У сучасних умовах вибір конкурентної стратегії підприємства повинен здійснюватися на основі врахування індивідуальних уподобань споживачів та тих конкурентних переваг, якими володіє підприємство. Таке поєднання внутрішніх потенційних можливостей у задоволенні вибагливого попиту на конкурентних ринках забезпечить під- вищення ефективності діяльності підприємства в довгостроковій перспективі.

Аналіз останніх досліджень i публікацій. Проблематика підвищення конкурентоспроможності підприємства в довгостроковій перспективі $є$ однією з найбільш досліджених у науковій літературі. Від класиків теорії конкурентоспроможності (М. Портер, I. Анософф, А. Томпсон, Д. Рікардо, Ф. Котлера) досі питання формування конкурентних стратегій на основі реалізації конкурентних переваг підприємства не втратили свою актуальність $[1 ; 2 ; 3 ; 6]$, оскільки мінливість зовнішнього середовища ставить нові виклики та штовхає до необхідності постійних змін у їх стратегічних діях.

Мета статті полягає в порівняльному аналізі чинників формування та найкращої практики реалізації конкурентних стратегій підприємствами України.

Виклад основного матеріалу. Відповідно до класичного поняття, сформованого ще М. Портером, конкурентна стратегія - це сукупність способів i засобів досягнення цілей конкуренції, отримання стійких конкурентних переваг, задоволення потреб споживачів краще, ніж це роблять конкуренти. 
Розвиток стану конкуренції на ринку та вимог споживачів в епоху розвитку економіки знань обумовлений низкою як традиційних, так і нових чинників. В умовах розвитку ринкового середовища змінюється концепція ведення конкурентної боротьби, відбувається іiі переорієнтація 3 боротьби за право задоволення потреб клієнта в боротьбу за його усвідомленість вибору придбання. Такі зміни в підходах до розуміння конкуренції обумовлені сукупністю факторів, які характеризують зміни поведінки споживача на ринку, що вимагає відповідної зміни конкурентної стратегії підприємства, спрямованої на досягнення стратегічних цілей на конкурентному ринку через задоволення потреб споживачів.

Нобелівський лауреат Ричард Талер у 2017 році отримав премію за розроблення теорії поведінкової економіки, що зводиться до визначення ролі психології у формуванні економічної поведінки споживача. Ним було відзначено, що сучасні компанії, плануючи асортимент та формуючи цінову політику, давно використовують такі поведінкові характеристики споживача, як ірраціональність, прагнення до справедливості.

На основі своїх досліджень Р. Талер запропонував стратегію «лібертаріанского патерналізму», яка спрямована на те, щоби спонукати споживача до оптимального вибору, заснованого не на почуттях і спокусах, а на розумному усвідомленні потреби.

3 контексту досліджень Р. Талера випливає висновок про необхідність постійного впливу на формування та підтримання рішення про придбання товару споживачем. Інструментами формування конкурентної переваги підприємства, яка водночас виконує роль підсвідомого стимулу придбання відповідного товару споживачем, є імідж та інформаційний супровід властивостей товару. Товари відомих торгових марок, товари іміджевих підприємств, товари, зі властивостями яких споживач попередньо ознайомлений, мають вищу конкурентоспроможність на конкурентних ринках.

Задекларовані Р. Талером положення вимагають нових концептуальних підходів до зміни стратегії конкурентної поведінки підприємств на ринку. Усвідомлений вибір споживача - це результат планомірної реалізації стратегії формування підприємством сукупності конкурентних переваг продукції. В умовах динамічного розвитку економіки знань конкурентними перевагами продукції є іï унікальність, цінність для споживача, відповідність очікуванням. Зміни вподобань і стилю споживчої поведінки в сучасному світі трансформують як глобальний ринок, так і поведінку його учасників. Так, на ринку напоїв змінюються вподобання споживачів щодо збільшення кількості споживання напоїв без цукру, що спонукає виробників до реалізації стратегії диференціації. Так, якщо довгий час прибутки “Кока-Кола Беверіджиз Україна” фор- мувалися від продажу напою “Coca-Cola”, то нині $50 \%$ прибутку компанія отримує від продажу іншої продукції (газованих, енергетичних напоїв, соків, води та готового до вживання чаю). У світі компанія виробляє приблизно 3900 найменувань та близько 400 брендів напою. У стратегічному розвитку компанії спостерігається поступове зміщення акцентів з власне напою й бренду “Coca-Cola" в бік зростання важливості самої компанії як виробника найрізноманітніших напоїв [4].

Зміни вектору конкурентних стратегій та способів їх реалізації в сучасній економіці відбуваються також під дією низки макроекономічних чинників. Зокрема, зниження купівельної спроможності населення змусило авіакомпанію МАУ змінити стратегію конкуренції та оголосити себе низько тарифною мережевою авіакомпанією. Якщо у 2013 році тариф на 1 годину польоту складав 49 доларів, то у 2017 році він скоротився до 34 доларів [8].

Мережева модель авіакомпанії забезпечила зростання транзитного пасажиропотоку авіакомпанії та аеропорту Бориспіль, відповідно, зростання надходжень в економіку країни від реалізації ії хабової мережевої моделі. Така конкурентна стратегія забезпечила зростання частки авіаперевізника на українському ринку до 38,9\% за загального пасажиропотоку українських аеропортів у 20,55 млн. осіб [8].

Більшість авіакомпаній реалізує у своїй діяльності конкурентну стратегію концентрації, збільшуючи кількість повітряних суден та нарощуючи пасажиропотоки авіакомпанії, а також стратегію диференціації, проявом якої є розширення мережі маршрутів перевезення пасажирів.

Яскравим підтвердженням ролі інновацій як конкурентної переваги не лише підприємств, але й економік загалом є досвід розвитку сільського господарства в Ізраїлі, де лише 20\% землі придатні для агровиробництва. Сьогодні ця країна забезпечує свої потреби в продукції сільського господарства на 95\%. Така частка ізраїльських підприємств на їх національному ринку є результатом впровадження інноваційних рішень у сільське господарство. Чинником розвитку ізраїльського агровиробництва $є$ складні умови для ведення сільського господарства, які спонукають до розроблення та впровадження інноваційних рішень на всіх етапах його виробництва [9].

Сьогодні основними інноваційними рішеннями в системі заходів з активізації розвитку сільськогосподарського кооперативного виробництва Ізраїлю $є$ комп'ютеризовані методи зрошення, тепличні технології, технології заощадження води, зберігання продукції, збільшення врожайності, впровадження технологій збільшення надоїв [7].

В Ізраїлі один фермер годує 98 осіб, тоді як в Україні один фермер годує 10 осіб. Сьогодні в Ізраїлі найвищий рівень надою молока від однієї корови у світі, що в середньому становить 12,5 т 
на рік. Наприклад, у Німеччині цей показник становить близько 8,5-9 т на рік, у США - близько 10 т на рік, у СС - 6,9 т, в Індії - 1,2 т, у Китаї 2 т, у Російській Федерації - 3,6 т, а в Україні близько 4,6-5,4 т на рік [7].

Така стратегія розвитку ізраїльських кооперативів привела до набуття ізраїльськими підприємствами конкурентних переваг, які забезпечили країні здатність конкурувати на висококонкурентному європейському ринку. Розвиток конкурентоспроможних товарів забезпечив Ізраїлю у 2018 році 19 позицію в рейтингу глобальної конкурентоспроможності.

Українська економіка демонструє поступальні тенденції зростання своєї конкурентоспроможності не на рівні економіки загалом, а на рівні окремих підприємств. На відміну від Ізраїлю, який розвиває інтенсивний тип економіки, українські підприємства формують свої конкурентні стратегії завдяки розширенню географії своєї діяльності та реалізації конкурентних переваг на зовнішніх ринках. Конкурентні стратегії українських товаровиробників реалізують цілі формування лідерських позицій у витратах завдяки формуванню коротких логістичних ланцюгів, відповідно, менших, ніж у конкурентів доданих витрат.

Особливої актуальності стратегія лідерства у витратах набуває у корпораціях, для яких розмір витрат визначає ефективність, а інколи й доцільність експорту продукції у географічно віддалені країни. Так, забезпечення конкурентних переваг продукції підприємств олієжирової промисловості на ринках Китаю, африканському континенті, в країнах Далекого Сходу досягається шляхом формування власних логістичних ланцюгів, до складу яких входять агропідприємства, олієекстракційні заводи, елеватори, логістична інфраструктура, зернові термінали. Такі ланцюги дають змогу зменшити витрати на сировину, іiі зберігання, транспортування, відповідно, витрати виробництва.

Показовим є досвід реалізації стратегії лідерства на ринку ПрАТ «Оболонь», яка є незмінною протягом усієї історії іiі розвитку. Основним спонукальним чинником реалізації визначеної стратегії була значна ємність ринку пива за низької пропозиції та високого попиту.

Інструменти підтримки вибраної стратегії змінювалися під впливом ринкових вимог та можливостей корпорації щодо їх задоволення. Так, 3 1998 року корпорація почала реалізовувати стратегію абсолютної безпечності продукції, що підтверджується низкою сертифікатів на систему управління якістю (ISO 9001:2015), управління безпечністю харчових продуктів (ISO 22 000:2018), екологічне керування (ISO 14001:2015), управління безпекою та гігієною праці (ISO 45 001:2018).

У 1998 році в корпорації почалася реалізовуватися стратегія, спрямована на досягнення цілей власного задоволення потреб корпорації у сировинних ресурсах. Задля цього на Хмельниччині створена науково-виробнича асоціація «Нива Оболонь», що займається селекцією та промисловим розмноженням насіння перспективних сортів ячменю.

Окрім того, конкурентною перевагою підприємства стало постійне зростання продуктового портфеля та товарних марок.

Різкими змінами споживчих переваг як чинника розвитку відповідного ринку та формування конкурентних переваг продукції на цьому ринку $\epsilon$ індивідуалізація споживача, яка проявляється в його прагненні мати відповідні товари, які задовольняють його індивідуальні потреби або виокремлюють його в суспільному просторі. Такі зміни характерні для підприємств, які реалізують товари немасового виробництва (продукція легкої промисловості, ІТ-індустрія, поліграфія тощо). Конкурентні переваги продукції у таких виробництвах $є$ результатом реалізації творчих та креативних рішень.

Щодо розвитку IT технологій слід зауважити, що найбільша частка доданої вартості таких компаній формується на етапах R\&D, дизайну, маркетингу, стандартизації, логістики, обслуговування, тому конкурентні переваги виробників інформаційних продуктів зростають у корпораціях, які володіють науково-дослідними центрами, що проводять як наукові дослідження, так і виробництво пробних зразків продукції, мають сформовану IT- та логістичну інфраструктуру.

Висновки. Отже, на основі узагальнення досвіду реалізації конкурентних стратегій, які реалізуються провідними українськими та іноземними підприємствами, можна зазначити, що в сучасних умовах ринкової економіки поведінка споживача на ринку є основним джерелом ефективності конкурентної стратегії.

Основоположним ресурсом ведення конкурентної боротьби й побудови конкурентних стратегій підприємств є інновації. Випереджаючі інновації стратегічного значення й нові методи ведення конкурентної боротьби, згідно з дослідженнями провідних учених, повинні стати запорукою успішної реалізації конкурентних стратегій.

Якщо раніше головними конкурентними перевагами підприємства на ринку були ресурси та стандартний набір стратегічних рішень, то сьогодні - здатність виробляти унікальні товари. В сучасних умовах відмінність набула ознак властивості сучасного товару, а першість у пропозиції інноваційного товару на ринку забезпечує прибутковість підприємства.

Якщо унікальність є конкурентною перевагою товару, то здатність до прийняття нестандартних стратегічних рішень, заснованих на творчих та креативних ідеях, формує конкурентоспроможність підприємства. 


\section{Список використаних джерел:}

1. Бєлов С.В. Розробка конкурентної стратегії організації в умовах переходу до економіки знань. Молодий вчений. 2016. № 9. C. 487-491. URL: https://moluch.ru/archive/113/28920 (дата звернення: 30.01.2020).

2. Грановська В.Г. Конкурентні стратегії розвитку аграрних підприємств у глобалізованому світі. Вісник Сумського національного аграрного університету. Серія: Економіка і менеджмент. 2016. Вип. 1. С. 84-90.

3. Гуляєва Н.М., Бідюк А.М. Конкурентні стратегії закладів вищої освіти. Економічний вісник університету. 2018. Вип. 37 (1). С. 12-19.

4. Завжди Кока-Кола: глобальна компанія змінює власну бізнес-стратегію. URL: https://www.seeds.org.ua/zavzhdikoka-kola-globalna-kompaniya-zminyuye-vlasnu-biznes-strategiyu (дата звернення: 30.01.2020).

5. Индекс глобальной конкурентоспособности. URL: https:/gtmarket.ru/ratings/global-competitiveness-index/info (дата звернення: 30.01.2020).

6. Маховка В.М., Коршикова Н.В. Конкурентні стратегії підприємств, що діють на міжнародних ринках: сутність та види. Економіка. Управління. Інноваиіï. Серія: Економічні науки. 2017. № 1. URL: http://nbuv.gov.ua/UJRN/eui_2017_1_7 (дата звернення: 29.01.2020).

7. Сільське господарство Ізраїлю. URL: https://pdatu.edu.ua/news/1466-1466.html (дата звернення: 30.01.2020).

8. 10 пунктов МАУ: что задумала авиакомпания на ближайшие 5 лет. URL: https://cfts.org.ua/articles/10_punktov_ mau_chto zadumala_aviakompaniya_na_blizhayshie_5 let_1367 (дата звернення: 28.01.2020).

9. SUP Agro Day 2019: інновації, що забезпечать майбутнє України. URL: https://landlord.ua/news/sup-agro-day-2019innovatsii-shcho-zabezpechat-maibutnie-ukrainy (дата звернення: 28.01.2020).

\section{References:}

1. Bielov S.V. (2016) "Development of a competitive strategy of the organization in the transition to a knowledge economy", Molodyi vchenyi, № 9, pp. 487-491, available at: https://moluch.ru/archive/113/28920 (data zvernennia: 30.01.2020).

2. Hranovska V.H. (2016) "Competitive strategies for the development of agricultural enterprises in the globalized world", Visnyk Sumskoho natsionalnoho ahrarnoho universytetu. Seriia: Ekonomika i menedzhment, vyp. 1, pp. 84-90.

3. Huliaieva N.M., Bidiuk A.M. (2018) "Competitive strategies of institutions of higher education", Ekonomichnyi visnyk universytetu, vyp. 37 (1), pp. 12-19.

4. "Always Coca-Cola: a global company is changing its business strategy", available at: https://www.seeds.org.ua/zavzhdikoka-kola-globalna-kompaniya-zminyuye-vlasnu-biznes-strategiyu (accessed: 30 January 2020).

5. "Global Competitiveness Index", available at: https:/gtmarket.ru/ratings/global-competitiveness-index/info (accessed: 30 January 2020).

6. Makhovka V.M., Korshykova N.V. (2017) "Competitive strategies of enterprises operating in international markets: nature and types”, Ekonomika. Upravlinnia. Innovatsii. Seriia: Ekonomichni nauky, № 1, available at: http://nbuv.gov.ua/UJRN/ eui_2017_1_7 (accessed: 28 January 2020).

7. "The Agriculture of Israel", available at: https://pdatu.edu.ua/news/1466-1466.html (accessed: 30 January 2020).

8. "10 points UIA What did the airline plan for the next 5 years?", available at: https://cfts.org.ua/articles/10_punktov_mau_ chto zadumala aviakompaniya na blizhayshie 5 let 1367 (accessed: 28 January 2020).

9. "SUP Agro Day 2019: Inn̄ovätions that will secure Ukraine's future", available at: https://landlord.ua/news/sup-agro-day2019-innovatsii-shcho-zabezpechat-maibutnie-ukrainy (accessed: 28 January 2020).

Marchenko Valentyna

National Technical University of Ukraine "Igor Sikorsky Kyiv Polytechnic Institute"

\section{PRACTICAL EXPERIENCE OF IMPLEMENTING COMPETITION STRATEGIES OF ENTERPRISES}

The purpose of the article is to compare the factors of formation and best practice of implementation of competitive strategies by Ukrainian enterprises. The description of the implementation of competitive strategies by the leaders of the respective markets allowed to identify the evolution of the main means of their competitiveness and to summarize the main factors that influence the formation of competitive advantages of the enterprise in the market and determine the effectiveness of implementation of the selected competitive strategy. It is revealed that such factors are the ability of an enterprise to influence consumer behavior through directed information flow and unique product properties, the ability to meet consumer demand at the lowest cost, which is achieved through the formation of closed technological cycles and logistics chains, the ability to maintain market leadership in the market through policy renewal. Innovation and non-standard strategic decisions are the tools for the implementation of certain capabilities. It is revealed that in the modern economy there are significant changes both in consumer needs (individualization of needs) and in instruments of their satisfaction (personalization of sales). The competitive advantages of the enterprise, which ensure their competitiveness and compliance with consumer needs, are the structure of the portfolio of assortment items and brands, information support of product properties, confirmation of their safety and quality, the formation of complete technological cycles of production and logistics infrastructure, innovative production research centers and production of sample products. Changes in preferences and style of consumer behavior in today's world transform both the market and the behavior of its participants. It is established that in today's market economy, consumer behavior in the market is the main source of effectiveness of competitive strategy. The difference has become a feature of modern goods, and the superiority in the supply of innovative goods in the market ensures the profitability of the enterprise.

Key words: competitive strategies, competitive advantages, competition, enterprises, consumer behavior.

JEL classification: M20. 